DOI 10.31558/2519-2949.2020.2.8

УДК 323.22(437.6)(1-20)-048.74:336.14

ORCID ID: https://orcid.org/0000-0002-9047-8977

Цірнер М., Пряшівський університет (Словацька республіка)

ORCID ID: https://orcid.org/0000-0002-1640-2309

Марадик Н., Пряшівський університет (Словацька республіка)

\title{
ОСОБЛИВОСТІ ФІСКАЛЬНОЇ ДЕЦЕНТРАЛІЗАЦІЇ В СЛОВАЦЬКІЙ РЕСПУБЛІЦІ: ДОСВІД ДЛЯ УКРАЇНИ*
}

Розглядаються основні напрями реформування системи місиевого самоврядування у Словаџькій Республічі. Висвітлено історичні аспекти становлення місиевого самоврядування у Словаччині та здійснено системний аналіз адміністративної й територіальної реформ у державі. Проаналізовано особливості сучасного етапу децентралізачійних реформ, який став результатом низки ендогенних та екзогенних чинників. Автори детально проаналізували позитивні наслідки децентралізації та негативні тенденції, щзо супроводжують цеей процес. Зроблено висновок, щьо для утвердження України як демократичної і правової держсави принципово важливою є побудова дієвої системи місиевого самоврядування, спроможної своєчасно й ефективно задовольняти потреби громадян, сприяти реалізації їхніх прав. Важливу роль у реформуванні самоврядування відіграє децентралізація влади, що передбачає передачу значного обсягу завдань, функиій та повноважень з иентрального рівня на місиевий із належним їх розмежуванням між органами виконавчої влади $i$ місиевого самоврядування. Україна повинна навчитися не тільки з позитивних, а й з негативних аспектів та наслідків реформи державного управління.

В иілому, у Словаччині фінансові джерела розподілені між різними рівнями влади таким чином, що і регіони і уряд мають потужну фінансову базу для своєї діяльності, а держава здійснює трансферти до місиевих бюджетів не тому, що вони не можуть профінансувати свої мінімальні потреби (як ие має місие в Украйні), а на виконання делегованих функиій. Будучи повністю відповідальними за соціально-економічний стан відповідної адміністративно-територіальної одиниці, органи місиевого самоврядування проводять активну економічну політику, в тому числі в питаннях пошуку та залучення інвесторів. Це сприяе як розквіту регіонів, так і високій економічній динамічі Словачької республіки загалом.

Таким чином, реформи в Словачькій республічі призвели до становлення ефективної та динамічної моделі місчевого самоврядування. Подальша бюджетна реформа та фіскальна децентралізаиія зробили органи місиевого самоврядування фінансово незалежними від центральних органів влади.

Ключові слова: фіскальна децентралізачія, місиеве самоврядування, Словаччина, Україна, державне управління, локальна демократія.

Постановка проблеми. Проблема реформи державного управління на сьогодні $\epsilon$ надзвичайно актуальною, особливо для України, зважаючи на ситуацію, яка склалася в цій державі. Окреслена проблематика вже тривалий час перебуває в полі зору зарубіжних та вітчизняних науковців, зважаючи на успішний досвід iï реалізації в країнах Європейського Союзу. Серед них варто виділити праці відомих фахівців цієї галузі: О.Бетлія (Betliy) [1], С. Седлакову (Sedláková) [6], В.Дудінського, М.Лачного, В.Данчішина (Dudinsky, Lačny, Dančišyn) [3], Климовського (Klimovsky) [4]. У середині минулого століття дана тема була чи не найбільш актуальною політико-правовою темою у світі. Щодо країн пострадянського простору, а також країн Східної Свропи, цей процес розпочався тільки на початку 1990-х рр.

\footnotetext{
* Článok je čiastkovým výstupom grantovej úlohy VEGA 1/0177/19 Výzvy a perspektívy cezhraničnej spolupráce
} v kontexte implementácie Asociačnej dohody EÚ s Ukrajinou 
Однак на сьогодні вже можна вести мову про значний прогрес певних держав (наприклад, Польщі, Чехії, Словаччини) у цьому напрямі та про досягнення ними загальної мети: створення оптимальної системи територіального устрою; реформування органів державної влади та створення ефективного місцевого самоврядування; підвищення якості надання публічних послуг, покращення місцевої інфраструктури тощо.

У зв'язку з цим особливої актуальності набувають наукові дослідження зарубіжного досвіду реформування системи державного управління, насамперед тих держав, які мають близькі до українських «стартові умови» державного будівництва. Однією з таких держав, що має багато спільного з Україною і в далекому минулому, і в епоху «соціалістичного табору», є Словацька Республіка.

Культурна, мовна, історична та інша близькість двох сусідніх країн (Словаччини й України) $є$ беззаперечною. Через відмінності в розвитку (зокрема, політичному), починаючи $390-x$ років XX століття у цих країнах виникли й відмінності в структурі державного управління. На ці відмінності у розвитку сфери державного управління мала вплив не тільки специфіка внутрішньополітичної ситуації в країнах, але і різна їх позиція на міжнародній політичній арені. Словаччина увійшла до складу СС, НАТО, ОЕСР та інших євроатлантичних структур, утворила східний кордон Шенгенської зони та стала країною-учасницею V4 (Вишеградської групи), в той час як Україна пов'язана з іншими міжнародними політичними структурами [5].

Метою статті $\epsilon$ окреслення процесів децентралізації державного управління, а саме процесів фіскальної децентралізації у двох сусідніх країнах - Словаччині та Україні.

Виклад основного матеріалу. Дієвість місцевого самоврядування, а отже i успішність децентралізації; залежить від фінансової спроможності територіальних колективів. Найбільш ефективним засобом створення повноцінної матеріальної бази для місцевого самоврядування, а також мірилом демократичності держави і компетентності самоврядних органів $є$ фіскальна децентралізація. Досвід Європи визначає можливість фіскальної децентралізації шляхом децентралізації видатків (надання ресурсів на виконання певних функцій); доходів (закріплення за територіальними колективами права на певні доходи та на встановлення їх розміру); а також процесуальну і організаційну самостійність із використання коштів. До речі, існуючі в розглянутих європейських державах моделі фінансової децентралізації передбачають не лише наділення територіальних колективів ресурсами, але й впровадження дієвих механізмів нагляду і контролю за діяльністю органів самоврядування у бюджетно-фінансовій сфері збоку державних органів (органів виконавчої влади або ж незалежних аудиторів), а також ефективних відповідальності і санкцій. Позитивним прикладом для правової системи України можуть слугувати розгорнуті й структуровані переліки доходів місцевого самоврядування європейських країн, що забезпечують дійсне наповнення місцевих бюджетів [2, s.13].

Європейська модель самоврядування грунтується на принципах субсидіарності. Вони передбачають надання послуг місцевими владами на максимально наближеному до споживачів рівні, а також законність роботи самоврядних органів, що має вияв у негативній (загальнодозвільній) або позитивній (спеціально-дозвільній) регламентації діяльності цих органів. В українських умовах важливим $\epsilon$ максимально повне законодавче закріплення компетенції місцевого самоврядування з урахуванням норм ч. 2 ст.19 Конституції України, що передбачає позитивний принцип діяльності публічної адміністрації; а отже й вимагає докладного відображення в законі їх функцій і повноважень.

Попри спроби реформування, прийняття низки застарілих нині законодавчих актів і приєднання до міжнародних договорів Європи, місцеве самоврядування України так і не було перетворено на потужну й фінансово спроможну форму реалізації публічної влади. Самоврядуванню не було передано достатнього обсягу повноважень, так само не створено дієвих механізмів їх реалізації і матеріального забезпечення. Не сприяє посиленню самоврядування й існування великої кількості територіальних громад із малою чисельністю мешканців, а отже i потенційно незначними податковими відрахуваннями. Зазначені негативи посилюються недостатньо розвинутою правовою культурою суспільства, нездатного нині адекватно оцінювати й контролювати діяльність органів та посадових осіб самоврядування, брати безпосередню участь у вирішенні питань місцевого значення. Закономірним наслідком таких проблем є погіршення якості місцевих рад, відчуженість органів самоврядування від населення та їх корпоратизація, що за відсутності дієвого контролю й відповідальності призвело до остаточного перетворення їх на слухняні інструменти в руках політичних сил для задоволення власних амбіцій. Проблеми децентралізації на низовому рівні 
доповнюються неефективною державною регіональною політикою, нездатною стимулювати громади до саморозвитку і прояву місцевої ініціативи [7].

Одним із небагатьох успіхів усфері місцевого самоврядування України $\epsilon$ наявність доктринальних напрацювань для майбутньої реформи. Розгляд міжнародних актів Європи, національних законодавств європейських держав, наукової доктрини з здійснення децентралізації, а також реформаторських ініціатив та досвіду функціонування самоврядних громад і регіонів підтверджує відповідність демократичним стандартам Свропи і успішній європейській практиці українських програмних документів 3 децентралізації, розроблених до 2009 року. Зокрема, чинна Концепція реформи місцевого самоврядування, а також Концепція реформи адміністративнотериторіального устрою передбачають створення в Україні впорядкованої системи ефективного, фінансово спроможного та відповідального місцевого самоврядування 3 дієвими громадами на базовому рівні адміністративно-територіального устрою. Тому рекомендації зазначених документів залишаються актуальними для врахування керівництвом держави при підготовці адміністративної реформи й запровадження децентралізації влади, безвідносно до політичних поглядів i мотивації розробників цих програм. Ефективна децентралізація публічного адміністрування можлива лише при проведенні еквівалентної передачі органам місцевого самоврядування фінансових джерел. Передача повноважень без адекватного розширення фінансової бази буде мати наслідком перетворення органів місцевого самоврядування в інститути, що займаються пасивною реалізацією державної політики. За відсутності коштів вони не мають власних ресурсів для розвитку відповідної адміністративно-територіальної одиниці, і таким чином знімають з себе відповідальність за $\dddot{1}$ соціально-економічне становище. В такій ситуації органи місцевого самоврядування не мають відчутної політичної ваги, а провідну роль в питаннях регіонального розвитку продовжує відігравати держава, яка апріорі в даному питанні $є$ менш ефективним менеджером.

Бюджетна децентралізація сприяє підвищенню ефективності використання бюджетних коштів. Якщо бюджетними коштами розпоряджаються органи місцевого самоврядування, які як правило, формуються з представників місцевої еліти, що обізнані з місцевими проблемами, це сприяе більш ефективному використанню публічних грошових фондів. Під тиском відповідальності і загрози втратити владу на виборах, правлячі політичні сили намагаються задовольнити інтереси максимально великої кількості населення. Крім того, словацькі експерти досить резонно відмічають, що центральний уряд, який здебільшого займається загальнонаціональними завданнями та географічно локалізований в столиці, фізично не може орієнтуватися в проблемах різнорідних регіонів республіки. Через це він, базуючись на неповній інформації, об'єктивно нездатний ефективно витрачати бюджетні ресурси по багатьох напрямах [9].

Політична відповідальність органів місцевого самоврядування за стан їх населених пунктів призводить до зменшення обсягів корупції та нецільового використання коштів. Коли органи місцевого самоврядування мають власні кошти і повноваження щодо їх нарощування, громадська думка більш схильна бачити недоліки економічної політики в низькій компетентності органів місцевої влади. Крім того, в регіонах інформація про місцевих політиків і чиновників є більш доступною, а відповідальність персоніфікованою. Названі чинники накладають на провладну політичну силу політичну відповідальність за свою діяльність, змушуючи іiі представників працювати чесно та ефективно. В іншому випадку, правляча політична сила втратить владу. Якщо ж органи місцевої влади не несуть політичної відповідальності за стан населеного пункту чи регіону, то прорахунки економічної політики на регіональному рівні можна віднести на недостатнє фінансування з боку державного бюджету, як це поширено в Україні. Така ситуація є сприятливою для розквіту корупції та нецільового використання коштів.

Висновки. Таким чином, виходячи з досвіду Словаччини, Україні варто по-перше, спростити податкове законодавство. Простота і зрозумілість податкової системи країни $є$ одним з найбільш важливих чинників активізації бізнесу. В даному контексті, прийняття в Україні Податкового кодексу, який систематизує законодавство в одному документі, стане кроком вперед. Проте в урядовому проекті закладені досить складні механізми адміністрування податків, безліч різних доповнень та виключень. Також невирішеним залишається питання зближення податкового та бухгалтерського обліку.

По-друге, максимально вирівняти фіскальний простір. Наявність численних пільг та преференцій знижує рівень конкуренції, оскільки ставить різні компанії, галузі, та сектори економіки в нерівні умови. В такій ситуації підприємства роблять ставку не на те, щоб покращити 
якість та знизити ціну продукції, а на те, щоб здобути максимально можливу кількість пільг, збільшивши таким чином ціновий ресурс конкурентоспроможності своєї продукції. Замість того, щоб формувати та реалізовувати сталу стратегію розвитку, інвестори в Україні значну увагу приділяють оптимізації оподаткування. Необхідно також відмітити, що надання певним галузям податкових пільг відразу викликає ланцюгову реакцію. Нагадаємо, як після надання податкових пільг підприємствам українського гірничо-металургійного комплексу в 1999 році, аналогічні пільги почали лобіювати автомобільні, суднобудівні, хімічні та інші підприємства. Досвід Словаччини показує, що укріпити конкуренцію на ринках та підвищити іï ефективність можливо лише через створення рівних фіскальних умов для всіх учасників.

По-третє, запровадити чітку та прозору систему державної допомоги у тих секторах, які цього потребують. Попри те, що, як було зазначено, головною задачею в Україні має стати вирівнювання фіскального простору, $є$ досить обмежений перелік тих сегментів, де державна підтримка все-таки $€$ доцільною. На наш погляд, полегшені фіскальні режими повинні застосовуватися для вирішення двох головних завдань: підтримки інноваційної діяльності та подолання безробіття в депресивних регіонах. Податкові пільги мають бути обмеженими, надаватися виключно за умови виконання деяких вимог (запровадження новітніх технологій, створення робочих місць для висококваліфікованих робітників, тощо). Державна допомога в у вигляді податкових пільг має надаватися лише з розрахунку на те, що віддача у середньостроковій перспективі перевищить обсяг втрат бюджету від надання таких пільг.

По-четверте, запровадити максимальний рівень прозорості державних фінансових потоків. Прозорість фінансових потоків є найбільш дієвим інструментом подолання корупції. На офіційних сайтах органів державної і місцевої влади Словаччини можна знайти не лише детальний перелік всіх проектів, які фінансуються з державного бюджету, а і кожен об'єкт і обсяг фінансування. Крім того, там можна знайти інформацію про державні закупівлі та рахунки-фактури, оплачені місцевими та регіональними органами влади. Це дозволяе наочно моніторити ефективність використання державних коштів. Аналогічний підхід і до тих компаній, які отримали державну допомогу. Вони зобов'язані надавати досить детальну інформацію про те, який обсяг пільг отримали, куди вона була спрямована, і які результати вдалося досягнути завдяки ії використанню.

По-пяте, переглянути та чітко структуризувати перелік власних та делегованих повноважень, що реалізують органи місцевого самоврядування. Наразі в Україні діє досить заплутана система розподілу функцій публічного адміністрування. Значна частина 3 них передана на місцевий рівень, але віднесена не до компетенції органів місцевого самоврядування, а до компетенції місцевих державних адміністрацій. Ключовою проблемою в Україні сьогодні є не стільки децентралізації функцій, скільки передача їх від місцевих державних органів влади до органів місцевого самоврядування. Держава має зберегти лише контрольні функції на регіональному рівні.

По-шосте, розпочати процес децентралізації державних фінансів. Децентралізація фінансів дозволить сформувати фінансово стійкі та економічно автономні регіони, які здатні проводити активну політику. Місцева влада Словаччини та Польщі, будучи повністю відповідальною за соціально-економічний стан відповідної адміністративно-територіальної одиниці, проводить активну економічну політику в тому числі в питаннях пошуку та залучення інвесторів. Оскільки місцева влада більш обізнана з можливостями та проблемами регіону, їх співпраця з інвесторами $\epsilon$ ефективнішою, аніж якби інвестори вели діалог з центральним урядом. Показовими є потужні індустріальні парки, створені в Словаччині місцевими органи влади. Така ситуація в Словаччині відчутно контрастує з в'ялою економічною активністю місцевої влади в Україні, яка будучи перетворена на інструмент реалізації державної політики, не маючи повноважень та фінансових ресурсів, здебільшого займається лише локальними проблемами.

По-сьоме, продовжити бюджетну децентралізацію з тим, щоб місцеві органи влади мали змогу самостійно фінансувати реалізацію власних функцій. Для цього має бути розширений кошик доходів бюджетів органів місцевого самоврядування. Це також дозволить спростити та прискорити рух грошових коштів. Оскільки в Україні абсолютна більшість регіонів отримують з державного бюджету трансферти вирівнювання, то раціональнішим здається закріплення за місцевими бюджетами додаткових джерел, що виключить тим самим з перерозподільного процесу ланку державного бюджету, наявність якої має наслідком додаткові транзакційні витрати. Крім того, варто розглянути можливість запровадження фіскально-ефективного і економічно обгрунтованого податку на використання громадського простору.

По-восьме, запровадити формульний розрахунок перерозподілу національних податків, 
закріплених за місцевими бюджетами. Наразі в Україні на процес перерозподілу бюджетних коштів чиниться значний політичний тиск. Для того, щоб мінімізувати цей суб'єктивний процесу та забезпечити економічну обгрунтованість даного процесу потрібно поширити практику формульного розрахунку розподілу загальнонаціональних податків. Для прикладу, нинішній механізм перерозподілу податку з доходів фізичних осіб, згідно якого він спрямовується за місцем реєстрації платника податків, який виступає податковим агентом з нарахування та сплати податку, призводить до того, що більшу частину даного податку акумулюють ділові центри України. Навіть якщо окремі філіали компаній функціонують в регіоні, і влада фінансує надання публічних товарів та послуг під відповідну кількість працівників, податок сплачується за місцем реєстрації компанії, а не за місцем роботи відповідного філіалу. Таким чином, регіони, передусім слабо розвинуті, отримують менше коштів від даного податку попри те що вони, навпаки, потребують більше коштів для стимулювання ділової активності. Враховуючи, що серед завдань податкової реформи часто називається перехід до консолідованої звітності, існує ризик що даний податок взагалі буде сплачуватися лише в обласних центрах та Києві. В даному контексті, більш доцільним виглядає словацький механізм, за якого єдиний фонд надходжень формується з податку з доходів фізичних осіб і перерозподіл його відбувається через застосування формульного підходу, який має спиратися на кількість офіційно зареєстрованих жителів на відповідній території.

\section{Бібліографічний список/References:}

1. Betliy O. Fiscal Decentralization in Ukraine: Is It Run Smoothly? 4liberty.eu. 2018. Review (9): 124-137. URL: <http://4liberty.eu/wp-content/uploads/2018/11/OLEKSANDRA-BETLIY_FISCAL-DECENTRALIZATIONIN-UKRAINE-IS-IT-RUN-SMOOTHLY.pdf >. (Access date: 2019-10-12).

2. Cirner M. Cezhraničná spolupráca v Európe a verejná správa naprieč hranicou (Slovensko - Ukrajina). Prešov: ADIN, s. r. o., 2017. 65 s.

3. Dudinský V.The analysis of cross-border cooperation between the Slovak Republic and Ukraine / Vladislav Dudinský, Vladimír Dančišin, Martin Lačný. Annales Scientia Politica. Vol. 6. No.1 (2017). P. 46-56.

4. Klimovský D. Samosprávy v EÚ: Ukrajina: Existencia neprehl’adnej samosprávy v politicky rozdelenej krajine. In: Územná samospráva. 2012. roč. 8, č. 3. S. $46-50$.

5. Ministerstvo zahraničných vecí a európskych záležitostí. Ekonomická informácia o teritóriu. Ukrajina. Ministerstvo zahraničných vecí a európskych záležitostí 2018.

URL: <https://www.mzv.sk/documents/746990/620840/Ukrajina++ekonomick\%C3\%A9+inform\%C3\%A1cie+o+terit \%C3\%B3riu+2018>. (Access date: 2019-10-10).

6. Sedláková S. Fiškálna decentralizácia - jej význam a dôsledky pre územnú samosprávu. Ekf.tuke.sk 2008. URL : 〈http://www3.ekf.tuke.sk/konfera2008/zbornik/files/prispevky/sedlakova.pdf>. (Acess date : 2019-11-11).

7. Sydorchuk O. Decentralization reform in Ukraine: prospects and challenges. Policy Bried 2015. URL: <http://dif.org.ua/modules/pages/fi les/1449069764_3870.pdf>. (Acess date : 2019-10-11).

8. Tichý D. Financovanie prenesených kompetencií. Aktuálne problémy fiškálnej decentralizácie na Slovensku (II). Verejná správa. 2003. URL: 〈http://www.angelfire.com/planet/dusan_kozovsky/PDF/VS122003.pdf〉. (Acess date : 2019-10-14).

9. Turanský V. Samosprávne kraje doplatia na daň z motorových vozidiel. Hnporadna.hnonline.sk 2014. URL: <http://hnporadna.hnonline.sk/clanky/541320-samospravne-kraje-doplatia-na-dan-z-motorovych-vozidiel>. (Acess date :2019-10-19).

\section{Cirner M., Maradyk N. Peculiarities of fiscal decentralization in the Slovak republic: experience for Ukraine}

The main directions of the reform of the system of public administration in the Slovak Republic and Ukraine are considered. The historical aspects of theestablishment of local self-government in Slovakia and Ukraine are covered and systematic analysis of administrative and territorial reforms in the states is carried out. The peculiarities of the present stage of decentralization reforms, which resulted from a number of endogenous and exogenous factors, were analyzed. The authors analyzed in detail the positive effects of decentralization and the negative trends that accompany this process. It is concluded that the establishment of an effective system of local selfgovernment, which is capable of meeting the needs of citizens in a timely and effective manner, and promoting the realization of their rights, is crucial for the establishment of Ukraine as a democratic and rule-of-state.

Decentralization of power plays an important role in self-government reform, which involves the transfer of a significant amount of tasks, functions and powers from the central level to local ones, with their proper separation between executive authorities and local self-government. Ukraine must 
learn not only from positive but also from the negative aspects and consequences of public administration reform.

Fiscal decentralization in Ukraine has advanced significantly since 2014, which means a much larger amount of funds for local government in Ukraine. Along with municipal reform, when small housing units are merged into larger units, more efficient, effective and cost-effective municipal management costs, investment projects, and the actual implementation of municipal responsibilities in different areas are realized. However, it should not be forgotten that fiscal decentralization is an increase in self-government budgets as a result of the transfer of competences from the state to self-government. At the same time, the property of the state to be taken care of (reconstruction and overhead) is transferred to local or regional self-government; The mere inflow of funds into municipalities, cities and regions does not mean that they will automatically develop. Strategic planning and control mechanisms will play an important role in maximizing the use of resources for public benefit.

Key words: fiscal decentralization, local government, Slovakia, Ukraine, public administration, local democracy. 